\title{
ANALYSIS OF FATTY DEGENERATION OF THE TRAPEZIUS MUSCLE AFTER USE OF ACCESSORY NERVE
}

\author{
ANÁLISE DA DEGENERAÇÃO GORDUROSA DO MÚSCULO \\ TRAPÉZIO APÓS USO DO NERVO ACESSÓRIO
}

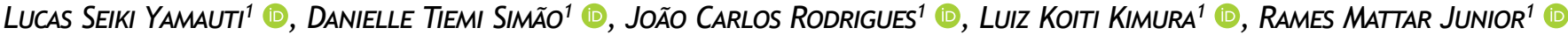 \\ 1. Universidade de São Paulo, Hospital das Clínicas, Medical School, Institute of Orthopedics and Traumatology, Hand and Microsurgery Group, São Paulo, SP, Brazil.
}

\section{ABSTRACT}

Objective: To investigate, through magnetic resonance imaging, the occurrence of fatty degeneration of the trapezius in adult patients undergoing nerve transfer procedure, using the spinal accessory nerve. Methods: A total of 13 patients meeting the criteria of unilateral brachial plexus injury and more than one year of postoperative care after nerve transfer surgery underwent an MRI scan of the trapezius. A T1-weighted 3D sequence was used, with the IDEAL technique using $8.0 \mathrm{~mm}$ cut thickness, $8.0 \mathrm{~mm}$ cut spacing, TR of $100 \mathrm{~ms}$, TE of $3.45 \mathrm{~ms}$, flip angle of 10 degrees, 20 cuts, on the sagittal plane. The images of the upper, transverse and lower parts of the trapezius muscle were then classified according to the degree of fatty degeneration, compared with the contralateral side, using the Goutallier score. Results: For the upper trapezius there was a change of the degeneration state in $23 \%(p=0.083)$, for the transverse section there was a change in $84.6 \%(p=0.003)$, for the lower one there was a change in $92.3 \%(p=0.002)$. Conclusion: The upper trapezius did not undergo significant degeneration after transfer. The lower and transverse trapezius suffered fatty degeneration in most patients, indicating severe functional impairment. Level of Evidence IV, Case series.

Keywords: Accessory Nerve. Nerve Transfer. Muscle, Skeletal/ Innervation. Magnetic Resonance Imaging.

\section{RESUMO}

Objetivo: Através de imagens de ressonância magnética, investigar a ocorrência de degeneração gordurosa no músculo trapézio em pacientes adultos submetidos a procedimento de transferência de nervo envolvendo o nervo espinal acessório. Métodos: 13 pacientes com lesão do plexo braquial unilateral e mais de um ano de cirurgia de transferência de nervo utilizando o nervo espinal acessório foram submetidos a exame de ressonância magnética do músculo trapézio. Foi obtida uma sequência 3D ponderada em T1, com a técnica IDEAL, espessura de corte de $8,0 \mathrm{~mm}$, espaçamento entre os cortes de $8,0 \mathrm{~mm}$, TR de $100 \mathrm{~ms}$, TE de 3,45 ms, flip angle de 10 graus e 20 cortes, no plano sagital. As imagens das porções superior, transversa e inferior do músculo trapézio foram classificadas de acordo com o grau de degeneração gordurosa e comparadas com o lado contralateral, utilizando o score de Goutallier. Resultados: Para o trapézio superior houve mudança no estado de degeneração em 23\% ( $p=0,083)$, para o trapézio transverso houve mudança em $84,6 \%(p=0,003)$, e para o trapézio inferior houve mudança em $92,3 \%(p=0,002)$. Conclusão: O trapézio superior não sofreu degeneração significativa após transferência. Os trapézios inferiores e médios sofreram degeneração gordurosa na maioria dos pacientes, indicando comprometimento funcional severo. Nível de Evidência IV, Série de casos.

Descritores: Nervo Acessório. Transferência de Nervo. Músculo Esquelético/Inervação. Imagem por Ressonância Magnética.

Citation: Yamauti LS, Simão DT, Rodrigues JC, Kimura LK, Mattar R Jr. Analysis of fatty degeneration of the trapezius muscle after use of accessory nerve. Acta Ortop Bras. [online]. 2020;28(4):186-9. Available from URL: http://www.scielo.br/aob.

\section{INTRODUCTION}

The accessory spinal nerve originates from cranial and spinal nerve roots in the posterior cranial fossa and innervates the sternocleidomastoid and the trapezius. After providing innervation to the sternocleidomastoid, the nerve descends obliquely into the posterior triangle of the neck. It branches (two to three branches in most cases) in the upper portion, before entering the trapezius. Intramuscularly, the nerve follows an oblique caudal course toward the middle and lower portion of the trapezius, branching to the muscle throughout its course. ${ }^{1}$

The accessory spinal nerve is often sacrificed and used in surgeries to repair brachial plexus lesions. ${ }^{2}$ Brachial plexus injury is usually caused by high-energy trauma, mainly involving the

All authors declare no potential conflict of interest related to this article.

The study was conducted at Universidade de São Paulo, Hospital das Clínicas (HCFMUSP), Medical School, Institute of Orthopedics and Traumatology, Hand and Microsurgery Group. Correspondence: Lucas Seiki Yamauti. Rua Doutor Ovídio Pires de Campos, 333, São Paulo, SP, Brazil, 05403-010. lucasyamauti.abc@gmail.com 
traction mechanism, causing partial or total ruptures of nerve roots in the cervical spine and leading to severe dysfunction of the affected upper limb. ${ }^{3}$

The accessory spinal nerve is used in nerve transfers in the repair of high brachial plexus lesions and also as a motor nerve in free muscle flaps, usually with the aim of regaining shoulder and elbow function. ${ }^{4,5}$ This is due to the fact that the accessory spinal nerve is purely motor and close to the brachial plexus in the suprascapular region. ${ }^{6}$

It is possible to preserve function of the upper trapezius in nerve transfers, when the accessory spinal nerve is sectioned distal to the point of branching in the upper portion. ${ }^{1}$

The literature shows that partial or even total function of the trapezius can be maintained after injury to the accessory spinal nerve, since the trapezius also receives direct innervation of cervical roots., ${ }^{1,-9}$ Therefore, there is still no understanding of how the trapezius evolves, especially its transverse and inferior portions, after the use of the accessory spinal nerve in nerve transfers.

The aim of this study is to investigate, through magnetic resonance imaging, the occurrence of fatty degeneration of the trapezius (upper, transverse and inferior portions) compared to the contralateral side, in patients submitted to the nerve transfer procedure using the accessory spinal nerve.

\section{MATERIALS AND METHODS}

\section{Study design}

Thirteen adult patients with total or partial traumatic injury of the brachial plexus, with preserved trapezius and submitted to sacrifices and uses of the accessory spinal nerve, more than one year after surgery, underwent magnetic resonance imaging of the trapezius muscle after signing the informed consent form.

Patients with indication for muscle transfers were prioritized for gaining external rotation of the shoulder and requiring detailed evaluation of trapezius trophism.

\section{Positioning and acquisition of images}

All images were obtained in a device with a magnetic field of $1.5 \mathrm{~T}$ (HDXT, General Eletric, Milwaukke, USA).

To acquire the images, the patients were positioned in horizontal supine position, with the cervical-thoracic transition located in the isocenter of the equipment using a 16-channel cardiac coil (General Eletric, Milwaukke, USA). Initially, a tri-planar locator image was obtained with the echo gradient technique, echo time (ET) of $5 \mathrm{~ms}$ and repetition time (TR) of $15 \mathrm{~ms}$. Next, a 3D sequence weighted in T1 was obtained, with the IDEAL technique (iterative decomposition of water and fat, with echo asymmetry) using cutting thickness of $8.0 \mathrm{~mm}$, spacing between the cuts of $8.0 \mathrm{~mm}$, TR of $100 \mathrm{~ms}$, ET of $3.45 \mathrm{~ms}$, flip angle (FA) of 10 degrees, 20 cuts, oriented in the sagittal plane, favoring both the trapezius on the same side of the accessory nerve sacrificed, and the contralateral side without the lesion, using as reference its muscular origin in the spine and its distal insertion in the clavicle and spine of the scapula.

\section{Image analysis}

As a method to evaluate the evolution of the trapezius, for each patient, we used the classification of Goutallier et al. ${ }^{10}$ modified by Fuchs et al. ${ }^{11}$ for magnetic resonance imaging on the side where there was brachial plexus injury and on the side where there was no lesion, as control.
Classification consists of five stages ranging from Stage 0 (normal muscle) to Stage 4 (more fat than muscle). The classification is described in Table 1.

Table 1. Description of the classification of Goutallier et al. ${ }^{10}$ modified by Fuchs et al. ${ }^{11}$

\begin{tabular}{c|c|c|c|c|c}
\hline Stage & $\mathbf{0}$ & $\mathbf{I}$ & II & III & IV \\
\hline Description & $\begin{array}{c}\text { Completely } \\
\text { normal, no } \\
\text { fat bands. }\end{array}$ & $\begin{array}{c}\text { Muscle } \\
\text { with } \\
\text { some fat } \\
\text { bands. }\end{array}$ & $\begin{array}{c}\text { Important fatty } \\
\text { infiltration, but } \\
\text { there is more } \\
\text { muscle than fat. }\end{array}$ & $\begin{array}{c}\text { Muscle and } \\
\text { fat in equal } \\
\text { amounts. }\end{array}$ & $\begin{array}{c}\text { More } \\
\text { fat than } \\
\text { muscle. }\end{array}$ \\
\hline
\end{tabular}

The magnetic resonance images of the trapezius of the patients were evaluated by two observers, working independently and classified according to Goutallier et al. ${ }^{10}$ Side images were classified with brachial plexus injury/sacrifice of the accessory spinal nerve and the uninjured side. Then a consensus was established after a meeting with the two observers, reanalyzing the images, and reaching a single classification for cases that were initially classified in different stages by them.

\section{Statistical analysis method}

The data, the characteristics of patients and the Goutallier classification of the control (non-operated) side as well as the operated side were stored in an Excel spreadsheet ${ }^{\circledR}$ for Mac and later imported into the SPSS25 software ${ }^{\circledR}$ for MAC.

Categorical data were described by their frequency and their respective proportion and the continuous data by the mean and its respective standard deviation.

To verify whether there was a change in the Goutallier score between the sides of the 13 individuals analyzed, an inferential analysis was performed, using the nonparametric test for paired measurements, Wilcoxon Signed-Rank test. It was accepted as a statistically significant difference when the $p$ value $\leq 0.05$.

The study was approved by the Ethics Committee of the Institution under number 1188 IOT Protocol and the Free and Informed Consent Form was signed by all participants.

\section{RESULTS}

Of the 13 study participants, 12 were male and one female, representing a percentage of $92.3 \%$ male and $7.7 \%$ female.

The mean age was $40.62 \pm 10.67$ years.

Nine patients (69.2\%) presented high partial brachial plexus injury and four patients (30.8\%) presented complete brachial plexus injury.

The mean time between brachial plexus injury and surgery with the use of accessory spinal nerve was $10.85 \pm 10.22$ months.

The mean time of postoperative care in procedures that used the accessory spinal nerve was $73.23 \pm 46.26$ months.

Eleven patients (84.5\%) underwent an accessory spinal nerve transfer to the suprascapular nerve and two patients underwent a free functional muscle transfer procedure with the gracilis muscle, using the accessory spinal nerve as the motor nerve.

Fatty degeneration of the trapezius was evaluated in the three portions of the muscle individually (upper trapezius, transverse trapezius and inferior trapezius) and on both sides, with the control being the side whose accessory spinal nerve was not sacrificed. The results of fatty degeneration according to the classification of Goutallier et al. ${ }^{10}$ modified by Fuchs et al. ${ }^{11}$ are shown in Table 2. 
Table 2. Results of the analysis of fatty degeneration of the trapezius according to the classification of Goutallier et al. ${ }^{10}$ modified by Fuchs et al. ${ }^{11}$

\begin{tabular}{|c|c|c|c|c|c|c|}
\hline $\begin{array}{c}\text { Goutallier } \\
\text { Classification }\end{array}$ & 0 & 1 & 2 & 3 & 4 & $\mathrm{p}$-value \\
\hline $\begin{array}{l}\text { Upper trapezius } \\
\text { (Control) } n(\%)\end{array}$ & $\begin{array}{c}13 \\
(100 \%) \\
\end{array}$ & 0 & 0 & 0 & 0 & \multirow{2}{*}{0.083} \\
\hline $\begin{array}{l}\text { Upper trapezius } \\
\text { (Operated) n (\%) }\end{array}$ & $\begin{array}{c}10 \\
(76.9 \%) \\
\end{array}$ & $\begin{array}{c}3 \\
(23.1 \%) \\
\end{array}$ & 0 & 0 & 0 & \\
\hline $\begin{array}{l}\text { Transversal trapezius } \\
\text { (Control) } n(\%)\end{array}$ & $\begin{array}{c}13 \\
(100 \%)\end{array}$ & 0 & 0 & 0 & 0 & \multirow{2}{*}{0.003} \\
\hline $\begin{array}{l}\text { Transversal trapezius } \\
\text { (Operated) } n(\%)\end{array}$ & $\begin{array}{c}2 \\
(15.4 \%) \\
\end{array}$ & $\begin{array}{c}3 \\
(23 \%) \\
\end{array}$ & 0 & $\begin{array}{c}4 \\
(30.8 \%) \\
\end{array}$ & $\begin{array}{c}4 \\
(30.8 \%) \\
\end{array}$ & \\
\hline $\begin{array}{l}\text { Lower trapezius } \\
\text { (Control) } n(\%)\end{array}$ & $\begin{array}{c}13 \\
(100 \%)\end{array}$ & 0 & 0 & 0 & 0 & \multirow{2}{*}{0.002} \\
\hline $\begin{array}{l}\text { Lower trapezius } \\
\text { (Operated) n (\%) }\end{array}$ & $\begin{array}{c}1 \\
(7.7 \%)\end{array}$ & $\begin{array}{c}1 \\
(7.7 \%)\end{array}$ & $\begin{array}{c}1 \\
(7.7 \%)\end{array}$ & $\begin{array}{c}2 \\
(15.4 \%)\end{array}$ & $\begin{array}{c}8 \\
(61.5 \%) \\
\end{array}$ & \\
\hline
\end{tabular}

\section{Upper trapezius}

Of the 13 participants recruited for the study, when comparing the control side with the operated side, the Goutallier score showed that there was a change in the state of fatty muscle degeneration in $23 \%$ of the individuals, from stage 0 to stage 1 (Figure 1). This observed modification was not statistically significant, with $p=0.083$.

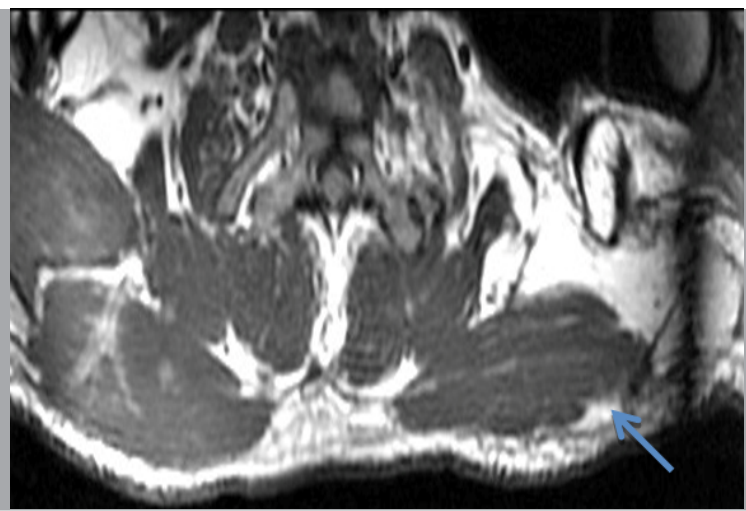

Figure 1. Axial cut image of the upper trapezius with injury to the right side of the image, rated as Goutallier score 1

\section{Transversal trapezius}

Of the 13 participants recruited for the study, when comparing the control side with the operated side, the Goutallier score showed that there was a change in the state of fatty muscle degeneration in $84.6 \%$ of the individuals, from stage 0 to stage 1 (Figure 1). With $23 \%$ for stage 1 and $61.6 \%$ for stage 3 (Figure 2 ) or 4 . This observed modification was not statistically significant, with $p=0.003$.



Figure 2. Axial cut image of the transversal trapezius with injury to the right side of the image, rated as Goutallier score 3.

\section{Lower trapezius}

Of the 13 participants recruited for the study, when comparing the control side with the operated side, the Goutallier score showed that there was a change in the state of fatty muscle degeneration in $92.3 \%$ of the individuals, from stage 0 to stage 1 (Figure 1). With $76.9 \%$ representing stage 3 or 4 (Figure $3 \mathrm{~A}-\mathrm{B}$ ). This observed modification was statistically significant, with $p=0.002$
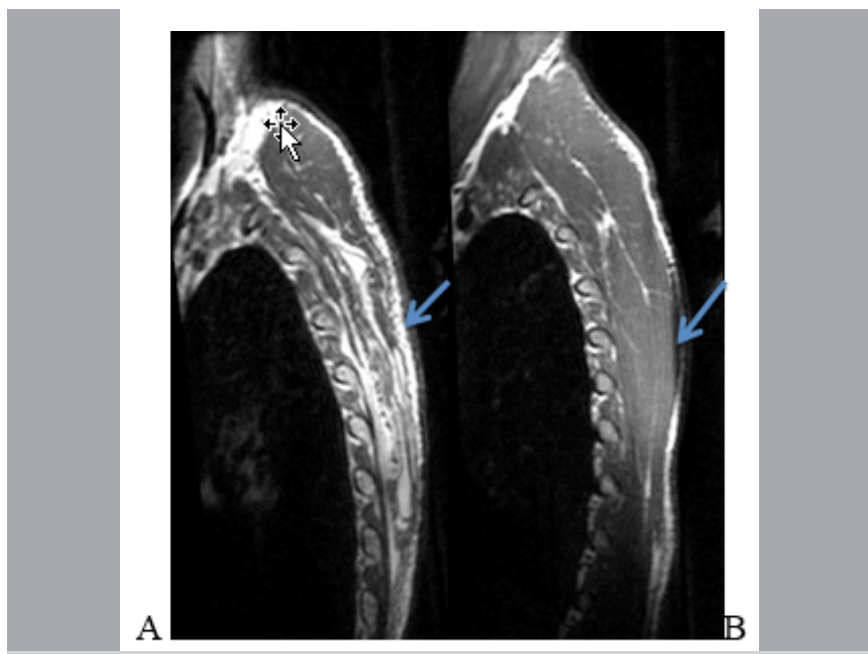

Figure 3. (A) Sagittal cut of the lower trapezius muscle rated Goutallier score 4. (B) Image of the control/contralateral side, without brachial plexus lesion/accessory spinal nerve sacrifice

\section{DISCUSSION}

In traumatic brachial plexus injuries, there is a prevalence of involvement in males (about 89\%), with an age range between 14 and 63 years and an average of 29 years. ${ }^{3}$ In the present study, $92.5 \%$ were male aged between 29 and 64 years and mean $40.62 \pm 10.67$ years. The mean time between brachial plexus injury and surgery with the use of accessory spinal nerve was $10.85 \pm 10.22$ months. The time was longer (over one year) in both cases in which the accessory spinal nerve was used as a motor nerve for free muscle transfer (gracilis muscle to brachial biceps muscle).

For nerve transfer procedures it is established that the maximum acceptable time is up to one year of brachial plexus injury. ${ }^{2}$

The 11 cases that underwent an accessory spinal nerve transfer procedure to the suprascapular nerve were operated less than one year after brachial plexus injury, as the literature suggests.

The minimum evaluation time established of one year after surgery is due to evidence that, after one year of nerve injury, irreversible loss of motor neural plaques occurs due to degeneration and fibrosis. ${ }^{12}$ As the aim of this study is to evaluate fatty degeneration, we consider that after one year of sacrifice of the accessory spinal nerve, the areas innervated by it have already suffered degeneration, remaining only nerve stimuli by the direct cervical branches.

Magnetic resonance imaging was chosen as it was capable of identifying and quantifying, in a noninvasive way, the morphology and muscular physiology. It is an examination already used in other studies to evaluate the appearance of the denervated muscle, which presents as characteristic the fatty degeneration. ${ }^{13-15}$ There is no previous study using magnetic resonance imaging to assess fatty degeneration of the trapezius after use or injury of the accessory spinal nerve.

The classification of Goutallier et al. ${ }^{10}$ was originally developed for chronic ruptures of the rotator cuff tendons. Muscle tissue, after chronic rupture of the tendon, is known to atrophy and retract, 
and there's replacement of tissue by fat due to disuse. Subacute and chronic lesions of motor nerves are also known to evolve with atrophy and fatty replacement after nerve stimulation ceases, as demonstrated in studies of the evolution of the denervated muscle through magnetic resonance imaging. ${ }^{13}$ Although the pattern of tissue alterations in chronic lesions of the rotator cuff tendons and denervation are proven to be different, ${ }^{16}$ there is no validated classification for muscular alterations on magnetic resonance imaging after chronic injury of motor nerves.

There are several anatomical studies in the literature that evaluate trapezius innervation. Although they prove the relationship between the cervical roots and the trapezius, the results are very inconsistent. The point at which most studies converge is that direct innervations from cervical roots to the trapezius usually come from spinal nerves C3 and C4, but they cannot prove whether the transverse and lower portions of the muscle remain functional after a complete section of the accessory spinal nerve.

In the study by Soo et al.," in 29 of the 32 dissections performed, one or more connections were found between the roots of $\mathrm{C} 2$ and $\mathrm{C} 3$ with the accessory spinal nerve that were proximal in relation to the level of accessory section in nerve transfers. In Dailana et al. ${ }^{1}$ these connections were found in only five of the 20 dissections. In the most recent study by Tubbs et al. ${ }^{7}$ with dissection of 15 cadavers and using both sides, there was involvement of cervical roots in all cases. These motor fibers ran either independently or made connections to the accessory spinal nerve. Usually the fibers that originated from the roots of C2-C3 joined with the accessory spinal nerve before penetrating the muscle. The fibers resulting from the roots of $\mathrm{C} 3$ or $\mathrm{C} 4$ ran independently in the muscle. ${ }^{7}$ Kim et al. ${ }^{17}$ performed dissection of 24 patients with head and neck cancer, followed by electrical stimulation of the roots of $\mathrm{C} 2, \mathrm{C} 3$ and $\mathrm{C} 4$. C2 stimulation was responsive in the upper and transverse trapezius at 4 and $8 \%$, respectively. C3 and C4 obtained non-constant responses, but the $\mathrm{C} 4$ nerve was the one that transmitted the most response in the muscle, compared to the other roots. ${ }^{17} \mathrm{Pu}$ et al. ${ }^{9}$ conducted a study with electroneuromyography applied intraoperatively of the dissection of 34 necks. After complete sectioning of the accessory spinal nerve, stimulation of the $\mathrm{C} 2$ produced contractions in the entire muscle in one case and in the transverse and inferior portions in two cases. Contributions of C3 and C4 produced contractions in the upper and transverse portions in some patients but in none of the cases in the lower portion. It was found that, in most cases, C2 innervates the trapezium through communication with the accessory nerve and C3 and C4 innervate the muscle independently. In addition, it was found that the main innervation of the lower portion is the accessory spinal nerve. ${ }^{9}$

In the results of this study, the upper trapezius was little or not affected at all by the sacrifice of the accessory spinal nerve, and only $23.1 \%$ presented mild alterations in relation to the contralateral side. This corroborates Tubbs et al..$^{7}$ and Dailiana et al., ${ }^{1}$ because the upper trapezius can be preserved if the accessory spinal nerve is sectioned distal to the point where there was branching in the upper trapezius, a technique we routinely adopt in our service.

The transverse and lower portions of the trapezius were classified as Goutallier stage 3 or 4 , in $61.6 \%$ and $76.9 \%$ of the operated sides, respectively. Goutallier et al. ${ }^{10}$ identified that lesions of stages 3 and 4 correlate with severe functional impairment. Therefore, despite occurring in the minority of cases, these portions of the muscle may eventually remain functional and capable of being used in other procedures for the treatment of brachial plexus lesions, such as lower trapezius transfer to external rotators.

This study has some limitations as it has a small number of patients. Brachial plexus injury is a rare lesion, and the inclusion criteria used did not allow for a very large number of patients.

In addition, the Goutallier classification was not designed for denervations but for chronic injuries in the rotator cuff tendon. In the absence of a validated classification in the literature to assess fatty degeneration after denerving a muscle, we believe that this adaptation allows us to reliably evaluate fatty degeneration resulting directly from denervation, as we compare it with the healthy contralateral muscle.

\section{CONCLUSION}

The upper trapezius does not undergo significant fatty degeneration after surgeries to repair brachial plexus lesions using the accessory spinal nerve. On the other hand, the middle and lower portions suffered significant fatty degeneration in most patients, indicating severe functional impairment after use of the accessory spinal nerve.

AUTHORS' CONTRIBUTIONS: Each author contributed individually and significantly to the development of this article. LSY: was responsible for the data collection, compilation and analysis, acquisition and interpretation of scientific content and writing of the manuscript; DTS: was responsible for the intellectual and scientific design of the study, critical review and approval of the final version of the manuscript. JCR: was responsible for guidance, discussion of the study design, technical procedures and image acquisition; LKK: was responsible for discussing the design of the study and reviewing the scientific content; RMJ: supervision of the article.

\section{REFERENCES}

1. Dailiana ZH, Mehdian H, Gilbert A. Surgical anatomy of spinal accessory nerve: is trapezius functional deficit inevitable after division of the nerve? J Hand Surg Br. 2001;26(2):137-41.

2. Wolfe S, Hotchkiss R, Pederson W, Kozin S, Cohen M. Green's operative hand surgery. 7th ed. Philadelphia: Elsevier; 2017.

3. Smania N, Berto G, La Marchina E, Melotti C, Midiri A, Roncari L, et al. Rehabilitation of brachial plexus injuries in adults and children. Eur J Phys Rehabil Med. 2012;48(3):483-506.

4. Chuang DC, Carver N, Wei FC. Results of functioning free muscle transplantation for elbow flexion. J Hand Surg Am. 1996;21(6):1071-7.

5. Bertelli JA, Ghizoni MF. Results of spinal accessory to suprascapular nerve transfer in 110 patients with complete palsy of the brachial plexus. J Neurosurg Spine. 2016;24(6):990-5.

6. Rui J, Zhao X, Zhu Y, Gu Y, Lao J. Posterior approach for accessory-suprascapular nerve transfer: an electrophysiological outcomes study. J Hand Surg Eur Vol. 2013;38(3):242-7.

7. Tubbs RS, Shoja MM, Loukas M, Lancaster J, Mortazavi MM, Hattab EM, et al. Study of the cervical plexus innervation of the trapezius muscle. J Neurosurg Spine. 2011;14(5):626-9

8. Soo K-C, Hamlyn PJ, Pegington J, Westbury G. Anatomy of the accessory nerve and its cervical contributions in the neck. Head Neck Surg. 1986;9(2):111-5.

9. Pu YM, Tang EY, Yang XD. Trapezius muscle innervation from the spinal accessory nerve and branches of the cervical plexus. Int J Oral Maxillofac Surg 2008;37(6):567-72.
10. Goutallier D, Postel JM, Bernageau J, Lavau L, Voisin MC. Fatty muscle degeneration in cuff ruptures: pre- and postoperative evaluation by CT scan. Clin Orthop Relat Res. 1994;(304):78-83.

11. Fuchs B, Weishaupt D, Zanetti M, Hodler J, Gerber C. Fatty degeneration of the muscles of the rotator cuff: assessment by computed tomography versus magnetic resonance imaging. J Shoulder Elbow Surg. 1999;8(6):599-605.

12. Tung TH, Mackinnon SE. Nerve transfers: indications, techniques and outcomes. J Hand Surg Am. 2010;35(2):332-41.

13. Kamath S, Venkatanarasimha N, Walsh MA, Hughes PM. MRI appearance of muscle denervation. Skeletal Radiol. 2008;37(5):397-404.

14. Zhang J, Zhang G, Morrison B, Mori S, Sheikh KA. Magnetic resonance imaging of mouse skeletal muscle to measure denervation atrophy. Exp Neurol. 2008;212(2):448-57.

15. 1Weber MA, Wolf M, Wattjes MP. Imaging patterns of muscle atrophy. Semin Musculoskelet Radiol. 2018;22(3):299-306.

16. Gerber C, Meyer DC, Flück M, Valdivieso P, von Rechenberg B, Benn MC et al. Muscle degeneration associated with rotator cuff tendon release and/or denervation in sheep. Am J Sports Med. 2017;45(3):651-8.

17. Kim JH, Choi KY, Lee KH, Lee DJ, Park BJ, Rho YS. Motor innervation of the trapezius muscle: Intraoperative motor conduction study during neck dissection. ORL J Otorhinolaryngol Relat Spec. 2014;76(1):8-12. 